6. The Verkhovna Rada of Ukraine (2011), The Law of Ukraine "Tax Code of Ukraine", available at: https://zakon.rada.gov.ua/laws/show/2755-17\#Text (Accessed 9 April 2021).

7. Order of the Ministry of Finance of Ukraine (2015), "About the statement of forms of the tax declarations of a charge for places for parking of vehicles and a tourist tax", available at: https://zakon.rada.gov.ua/laws/show/z0912-15\#Text (Accessed 9 April 2021).

8. Cabinet of Ministers of Ukraine (2009), "Vehicle parking rules", available at: https://zakon.rada.gov.ua/laws/show/13422009-\%D0\%BF\#Text (Accessed 9 April 2021).

9. Cabinet of Ministers of Ukraine (2010), "The order of formation of tariffs for services on the maintenance of platforms for paid parking of vehicles", available at: https://zakon.rada.gov.ua/laws/show/258-2010-\%D0\%BF\#Text (Accessed 9 April 2021).

10. The Verkhovna Rada of Ukraine (2020), The Law of Ukraine "About the State Budget of Ukraine for 2021", available at: https://zakon.rada.gov.ua/laws/show/1082-20\#Text (Accessed 11 April 2021).

11. State web portal of the budget for citizens (according to the Ministry of Finance of Ukraine), available at: https://openbudget.gov.ua/ (Accessed 11 April 2021).

12. Barabash O. O. (2014), "The principle of fiscal sufficiency in the tax legislation of Ukraine". Natsionalnyi universytet «Lvivska politekhnika», [Online], available at: http://ena.lp.edu.ua:8080/bitstream/ntb/26483/1/10-46-50.pdf (Accessed 11 April 2021).

13. Official site of Lviv City Council, available at: https://city-adm.lviv.ua/public-information/budget/lviv/biudzhet-lvova-na2020-rik (Accessed 13 April 2021).

14. Lviv City Council (2011), "About modification of decisions of city council from 27.01.2011 № 120 and from 29.12 .2011 № $1072 "$, available

https://www8.cityadm.lviv.ua/inteam/uhvaly.nsf/(SearchForWeb)/E348855D179F4F11C225851B00530F5D?OpenDocumen $\mathrm{t}$ (Accessed 13 April 2021).

Дата подання публікації 05.05.2021 p.

УДК 336.14

Кузьмак О.М., д.е.н., професор

Kuzmak O. Doctor of Economic Sciences, Professor https://orcid.org/0000-0003-0394-0981

\title{
СВІТОВИЙ ДОСВІД ФОРМУВАННЯ БЮДЖЕТНОГО ПОТЕНЦАЛУ МІСЦЕВИХ ФІНАНСІВ В УМОВАХ ДЕЦЕНТРАЛІЗАЦІї
}

\section{Луцьький національний технічний університет}

У статті визначено, що відповідно до реформи децентралізації, актуальним на сьогодні аспектом $\epsilon$ дослідження світового досвіду формування та витрачання місцевих бюджетів. Досліджено бюджетний устрій країн Свропи. Економічна та фінансова децентралізація привела до формування міжурядових фінансових відносин, що поєднують у собі принципи як бюджетного унітаризму, так і бюджетного федералізму. Досліджено трактування поняття бюджетного унітаризму та федералізму. Проаналізовано частки доходів місцевих бюджетів у ВВП в країнах Європи. Досліджено, що В СС дев'ять країн використовують лише один рівень піддержавних органів влади (самоврядування); інші дванадцять країн мають два регіональні рівні (муніципалітети та регіони); тоді як решта сім мають три рівні нижче загальнодержавного (муніципалітети, регіони та суб'єкти посередницької діяльності). Визначено, що конституції деяких країн іноді взагалі не регулюють організацію місцевого самоврядування (наприклад, у США).

Оцінено досвід європейських країн щодо обсягу надходжень до бюджету від місцевих податків. Здійснено аналіз динаміки бюджетного потенціалу місцевих фінансів Рівненської області. Визначено, що найважливішим економічним інструментом $є$ бюджет, тоді як управління місцевими органами самоврядування відповідно до встановленого бюджету $є$ обов'язковим за законом у кожній країні. Запропоновано шляхи збільшення податкової складової бюджетного потенціалу місцевих фінансів. Окреслено шляхи пошуку альтернативних джерел наповнення місцевих бюджетів через впровадження неподаткових зборів.

Ключові слова: децентралізачія, місиеве самоврядування, місиеві бюджети, бюджетний унітаризм, бюджетний федералізм, бюджетний потенціал, доходи та видатки місчевих бюджетів. 


\title{
FOREIGN EXPERIENCE OF FORMATION OF BUDGET POTENTIAL OF LOCAL FINANCES IN THE CONDITIONS OF DECENTRALIZATION
}

\author{
Lutsk National Technical University
}

The article highlights that in accordance with the decentralization reform, the relevant aspect today is the study of world experience in the formation and spending of local budgets. The budget system of European countries is studied. Economic and financial decentralization has led to the formation of intergovernmental financial relations that combine the principles of both budgetary unitarism and fiscal federalism. The interpretation of the concept of budget unitarism and federalism is studied. The shares of local budget revenues in GDP in European countries are analyzed. It has been studied that in the EU, nine countries use only one level of sub-government (self-government); the other twelve countries have two regional levels (municipalities and regions); while the remaining seven are three levels below the national level (municipalities, regions and intermediaries). It is determined that the constitutions of some countries sometimes do not regulate the organization of local self-government at all (for example, in the USA).

An assessment of the experience of European countries in terms of budget revenues from local taxes. The analysis of dynamics of budgetary potential of local finances of the Rivne region is made. It is determined that the most important economic instrument is the budget, while the management of local governments in accordance with the established budget is mandatory by law in each country. Ways to increase the tax component of the budget potential of local finances are proposed. The ways of finding alternative sources of filling local budgets through the introduction of non-tax fees are outlined.

Key words: decentralization, local self-government, local budgets, budget unitarism, budget federalism, budget potential, revenues and expenditures of local budgets.

Постановка проблеми у загальному вигляді і її з важливими науковими та практичними завданнями. Актуальність дослідження обумовлена поглибленням глобалізацій них процесів, що сприяє реформі децентралізації. Саме тому необхідним є дослідження світового досвіду формування та витрачання місцевих бюджетів. Особливо варто звернути увагу на досвід найближчих країн сусідів.

Аналіз останніх досліджень, у яких започатковано вирішення проблеми. Окремі аспекти проблеми формування бюджетного потенціалу місцевих фінансів висвітлені в працях вітчизняних вчених, зокрема Л.В. Лисяк, М.К. Дяченко [1], В.I. Покась [2], І. О. Луніної [3], Проць Н.В. [4], та ін. Згадані вчені внесли великий вклад у розробку теоретичних та практичних аспектів бюджетного потенціалу місцевих фінансів. Не зважаючи на значну кількість публікацій в означеній проблематиці, серед вчених недостатньо досліджено питання щодо світового досвіду формування та витрачання місцевих бюджетів.

Цілі статті. Ключовими цілями статті є: необхідність у дослідженні формування бюджетного потенціалу місцевих фінансів у країнах Європи та США, визначення особливостей місцевого самоврядування у світовому досвіді, розуміння сутності поняття бюджетного унітаризму, дослідження динаміки бюджетного потенціалу місцевих фінансів Рівненської області.

Виклад основного матеріалу дослідження 3 повним обгрунтуванням отриманих наукових результатів. У світовій практиці так, як і у вітчизняній, місцеві фінанси виступають основною складовою фінансів органів місцевого самоврядування, при цьому місцеві бюджети формуються та затверджуються на окреми адміністративних територіях . « У Великобританії, Швеції, Норвегії, Нідерландах, наприклад, переважна частина соціально - економічних послуг надається на місцевому рівні і фінансується 3 муніципальних бюджетів » [5]. При формуванні місцевих бюджетів враховуються необхідність забезпечення фінансовими ресурсами органів місцевого самоврядування. В тому числі передбачено фінансування повноважень, що виконуються даними органами, які безпосередньо пов'язані із виконанням завдань місцевого значення. 
У кожній країні передбачений законодавством різний адміністративний устрій, окрім того в більшості країн спостерігаються відмінності в соціальній, економічній, навіть історичній умовах функціонування адміністративних одиниць, що формує взаємовідносини між усіма рівнями влади в окремій територіальній одиниці. У відповідності до даних відмінностей кожна країна індивідуально будує питання бюджетного процесу. В цілому у зарубіжних країнах можна виокремити два види організації бюджетних систем: унітаризм та федералізм.

Місцеве самоврядування стосується конкретних установ чи утворень, створених національними конституціями (Бразилія, Данія, Франція, Індія, Італія, Японія, Швеція), конституціями штатів (Австралія, США), звичайним законодавством вищого рівня центрального уряду (Нова Зеландія , Великобританія, більшість країн), провінційне чи державне законодавство (Канада, Пакистан) або під виконавчою владою (Китай) для надання комплексу конкретних послуг на відносно невеликій географічно визначеній території. Місцеве самоврядування $є$ більш широким поняттям і визначається як формулювання та здійснення колективних дій на місцевому рівні. Тому воно включає пряму та непряму роль офіційних установ місцевого самоврядування та урядових ієрархій, а також роль неформальних норм, мереж, громадських організацій та асоціацій сусідніх країн у проведенні колективних дій шляхом визначення системи мешкання та мешкання взаємодія мешканців та держави, прийняття колективних рішень та надання місцевих державних послуг [6].

В СС дев'ять країн використовують лише один рівень піддержавних органів влади (самоврядування); інші дванадцять країн мають два регіональні рівні (муніципалітети та регіони); тоді як решта сім мають три рівні нижче загальнодержавного (муніципалітети, регіони та суб'єкти посередницької діяльності).

У Словацькій Республіці та Чехії, компетенція була поступово передана від держави до територіального самоврядування, оскільки територіальне самоврядування було встановлено як нова частина державного управління під час процесу децентралізації [7]. Для побудови демократичного суспільства необхідно було зміцнити місцеве самоврядування новими компетенціями, які спочатку виконувались лише державними нормами, такими як дороги, реєстри, будівельні норми, соціальне обслуговування, охорона навколишнього середовища, спорт, театр, освіта туризм, охорона здоров'я, регіональний розвиток тощо.

У 2008 році в рамках прийняття бюджетного кодексу в Чеській Республіці було прийнято новий закон, який спочатку розширив єдиний критерій кількості жителів муніципалітету, перерахованих відповідно до коефіцієнтів певних категорій розміру за двома іншими новими критеріями - простою кількістю жителів та кадастровою площею муніципалітету. Про чергову зміну, яка відбулася у 2013 році у фінансуванні місцевого самоврядування в Чехії розрахунок доходів від муніципальних податків змінився, включивши ще один показник - кількість дітей, які відвідують школу або шкільний заклад у муніципалітеті, i одночасно були визначені нові розмірні групи муніципалітетів. Не менш важливою групою податкових надходжень $є$ також доходи від місцевих податків і зборів. В обох країнах ці доходи належать до власних надходжень, оскільки їх збирає муніципалітет. Словацькою Республікою, муніципалітети можуть стягувати вісім різних видів місцевих податків, але вони повинні стягувати місцеву плату за будівельні відходи та дрібні будівельні відходи. У Чеській Республіці муніципалітети можуть стягувати сім різних видів місцевих зборів та один податок - податок на нерухомість.

Неподаткові доходи складають у середньому $13 \%$ поточних доходів муніципалітетів Словацької Республіки та $11 \%$ у Чехії. Ці доходи в основному складаються 3 власних доходів та бізнесу з комунальною власністю. Муніципалітети 
найчастіше здають своє майно в оренду. Крім того, до неподаткових надходжень належать також адміністративні збори, які мешканці сплачують за надання послуг (наприклад, за послуги реєстру, перевірку підпису тощо).

Конституції деяких країн іноді взагалі не регулюють організацію місцевого самоврядування (наприклад, у США), але $є$ також країни, де ці відносини суворо регламентовані, наприклад в Бразилії. Основним джерелом правового регулювання владних відносин у цих суб'єктах $\epsilon$ статути самоврядування. У деяких землях (державний рівень) є випадки, коли федеральні утворення виконують функції місцевого самоврядування на додаток до своїх власних функцій. Це стосується, наприклад, кантонів Швейцарії, країн та міст Німеччини та Австрії (Берлін, Гамбург, Бремен та Відень).

Існує дві системи організації місцевого самоврядування: англо-американська та європейська. «Англо-американська система характеризується наявністю місцевого самоврядування на всіх рівнях федерації або державного утворення» [8]. При цьому адміністративно-територіальних одиниць загального характеру не існує. Європейська система характеризується поєднанням місцевого самоврядування та державного управління; крім того, він має інші форми, в яких місцеві органи самоврядування покладаються на певні функції державною адміністрацією.

Звідси випливає, що для того, щоб місцеві органи самоврядування могли надавати всі компетенції, їм потрібні фінансові ресурси, які вони можуть отримати 3 різних джерел. Найважливіший економічний інструментом $є$ бюджет, тоді як управління місцевими органами самоврядування відповідно до встановленого бюджету $\epsilon$ обов'язковим за законом у кожній країні.

У економічній літературі немає єдиного визначення поняття бюджетного унітаризму та федералізму. Як правило бюджетний унітаризм трактується як «форма міжурядових відносин, у якій активну політику щодо формування місцевих фінансів проводить центральна влада» [9, с. 512]. «Бюджетна система в унітарних країнах (наприклад Італія, Франція, Україна, Японія), як правило, представлена двома рівнями бюджетів (державний і місцеві бюджети). Слід зазначити, що унітаризм та федералізм в чистому вигляді зустрічаються доволі рідко, переважно бюджетні системи містять ознаки як унітаризму, так і федералізму» [9, с. 512]. При виборі форми функціонування бюджетної системи держави, потрібно враховувати державну доцільність, національні та суспільні інтереси, економічну ситуацію тощо.

Можемо спостерігати, що достатній рівень самостійності місцевої влади характерний як федеративним, так і унітарним країнам. Після прийняття у 1985 році Європейської хартії про місцеве самоврядування почався активний процес децентралізації. До даної хартії було приєднано 47 країн і в тому числі Україна.

Децентралізація як економічна, так i фінансова призвела до активного формування міжурядових відносин, які поєднали принципи як бюджетного унітаризму, так і бюджетного федералізму. При проведенні децентралізації почався активний процес перерозподілу функціоналу між владними органами з ухилом на регіональні та місцеві органи самоврядування. В результаті, на місцевому рівні було створено самостійні місцеві органи, які місцеве населення могло спокійно та повноцінно контролювати. Окрім того, процес децентралізації сприяв концентрації фінансових ресурсів на місцевих рівнях, задля можливості фінансувати покладені повноваження.

«Слід відзначити, що в європейських країнах дуже різняться показники частки доходів місцевих бюджетів у ВВП. Так, найбільше перерозподіляється ВВП через місцеві бюджети у Данії - 37,5\%, Швеції - 25,8 \%, Фінляндії - 23 \%. Польща, Великобританія, Чехія, Угорщина мають значення даного показника в межах 10-15\%. А такі країни, як Австрія, Німеччина, Бельгія, Словенія, Іспанія перерозподіляють 
через місцеві бюджети від 5до $10 \%$ ВВП. Як ми бачимо, у всіх трьох групах $\epsilon$ абсолютно різні по рівню розвитку країни » [10].

Хоча необхідно зауважити, що світовий досвід децентралізації показав, що сама децентралізація, зокрема і фінансових ресурсів, не може бути запорукою розвитку місцевих територіальних громад. Також можемо стверджувати, що на сьогодні практично немає універсального ефективного методу поділу доходів і видатків серед бюджетів на різних рівнях.

«Закономірним для всіх зарубіжних країн $є$ поділ місцевих бюджетів на два самостійні функціональні види - місцеві поточні (адміністративні) бюджети та місцеві бюджети розвитку (інвестиційні бюджети)» [2]. При формуванні місцевих бюджетів враховується поділ видатків на поточні і капітальні. Даний поділ бюджету є трішки умовним, що дозволяє виокремити першочергові видатки, та другорядні видатки місцевих бюджетів. Надходження до місцевих бюджетів складаються з місцевих податків і зборів, платежів, загальних субсидій, що надаються державною владою, та інших надходжень.

У загальному доходи місцевих бюджетів розвинених країн, як і в Україні, складаються із податкових та неподаткових надходжень. Податкові бюджетні надходження (до яких належать доходи від податків, зборів, інших обов'язкових платежів) є базисом бюджетних доходів. Неподаткові доходи відіграють значно меншу роль у складі доходів місцевих бюджетів, ніж податкові. Досвід країн Свропи та США показує загальну закономірність, відповідно до якої формування дохідної бази місцевої влади та місцевого самоврядування в основному визначається рівнем децентралізації влади в країні. «Лідерство за найбільшими частками від податкових надходжень у структурі сукупних доходів місцевих бюджетів займають Швеція (63 \%) та Швейцарія (59\%), а також Іспанія, Франція, Італія - більше 55\%. Але є країни, у яких ця частка коливається від 10 до $15 \%$. (Словаччина, Великобританія)». [10, 11]. «Місцеві податки формують близько $60 \%$ прибуткової бази місцевих органів влади у Швеції, $66 \%$ - у США, 72 \% в Австрії, 46\% - у Німеччині та у Швейцарії, 37\% - у Великобританії тощо. Система місцевого оподаткування в країнах вельми різноманітна. В Німеччині вона налічує 55 видів місцевих податків, в Італії - близько 70, у Франції - більше 40, в Бельгії - майже 100, а у Великобританії їх тільки 2» [11]. Тобто видно, що обсяг надходжень до бюджету від місцевих податків ніяк не пов’язаний з їх кількістю. У європейських країнах, переважно, виокремлено два - три основних податків, що складають основну частину доходів місцевих бюджетів.

Таблиия 1.

Динаміка бюджетного потенціалу місцевих фінансів Рівненської області за 2013-2019

рр., млн. грн.

\begin{tabular}{|l|c|c|c|c|c|c|c|}
\hline \multicolumn{1}{|c|}{ Показники } & \multicolumn{7}{|c|}{ Роки } \\
\cline { 2 - 8 } & 2013 & 2014 & 2015 & 2016 & 2017 & 2018 & 2019 \\
\hline $\begin{array}{l}\text { Податкова складова } \\
\text { бюджетного } \\
\text { потенціалу місцевих } \\
\text { фінансів, млн. грн. }\end{array}$ & 1114,32 & 1223 & 1453,24 & 1542,51 & 1619,35 & 1813,75 & 2706,3 \\
\hline $\begin{array}{l}\text { Неподаткова складова } \\
\text { бюджетного } \\
\text { потенціалу місцевих } \\
\text { фінансів, млн. грн. }\end{array}$ & 151,66 & 177,91 & 291,2 & 253,68 & 277,03 & 394,69 & 427,19 \\
\hline $\begin{array}{l}\text { Бюджетний потенціал } \\
\text { місцевих фінансів, } \\
\text { млн. грн. }\end{array}$ & 1278,98 & 1383,91 & 1742,44 & 1789,19 & 1936,38 & 2438,44 & 3572,49 \\
\hline
\end{tabular}

Отже, бачимо можливість в Україні збільшення ставок екологічних податків, 
окрім того необхідно підсилити контроль за сплатою саме екологічних податків, особливо актуальним $\epsilon$ дана пропозиція для регіонів 3 негативним екологічним становищем, в яких розміщена значна кількість великих промислових підприємств, спостерігається висока густота населення. Дані підприємства при відсутності значної модернізації характеризуються значним рівнем забруднення навколишнього середовища, що спричиняє значний рівень захворювань місцевого населення.

Надзвичайно необхідним для України на сьогодні $є$ наявність альтернативних джерел надходжень до місцевих бюджетів, яке можливе при введенні неподаткових зборів. При пошуку шляхів зростання надходжень до місцевих бюджетів потрібно звернути увагу на збори за оренду майна бюджетних установ і доходи бюджетних підприємств від реалізації майна. 3 однієї сторони, варто покращити діяльність органів місцевого самоврядування щодо модернізації об'єктів комунальної власності, це сприятиме зростанню привабливості даних об'єктів, це дозволить створити професійну систему оцінки майна та допоможе забезпечити здачу даного майна в оренду за ринковими цінами. 3 другої сторони, необхідне також підвищення контролю за рухом коштів, які одержують бюджетні підприємства від реалізації необоротних активів та різних матеріальних цінностей.

Висновки. Отже, не зважаючи на те, що існуючі проблеми формування та розподілу місцевих бюджетів, $є$ характерними для України, тому постає гостра необхідність вивчення світового досвіду децентралізації та впровадження передових практик для зростання надходжень до місцевих бюджетів, а в результаті і бюджетного потенціалу регіону. Необхідне також врахування світового досвіду щодо збалансування фінансових надходжень 3 витратами та виконанням функціональних обов'язків місцевими органами влади.

\section{Список бібліографічного опису:}

1. Лисяк Л.В., Дяченко М.К. Міжбюджетні трансферти як інструмент забезпечення соціально-економічного розвитку регіонів. Науковий вісник Чернігівського державного інституту економіки $i$ управління. Серія 1: Економіка. 2019. Вип. 2. С. 55-59.

2. Покась В.І. Формування основ фінансової автономії місцевого самоврядування. Фінанси Украӥни. 2018. № 8. С. 67-73.

3. Луніна І.О. Державні фінанси та реформування між бюджетних відносин: монографія. К.: «Наукова думка». 2006. 432 c.;

4. Проць Н.В. Формування податкових надходжень місцевих бюджетів в контексті бюджетної децентралізації. Фінансовий простір. №1 (17). 2015. С.221-227.

5. Бондаренко А. I. Вплив держави на формування місцевих бюджетів у країнах Європи. Теорія та практика державного управління. 2010. Вип. 4. C. 185-192. URL: http://nbuv.gov.ua/UJRN/Tpdu_2010_4_30.

6. Boadway, Robin W., and Anwar Shah. 2009. Fiscal Federalism: Principles and Practice of Multiorder Governance. Cambridge: Cambridge University Press, p. 620.

7. Fandel, P, Marišová, E., Malatinec, T. \& Lichnerová, I. (2019), Decentralization Policies in Public Administration in Slovakia and the Czech Republic, and Their Impact on Building Offices' Scale Efficiency. Administrative Sciences, MDPI, Open Access Journal, vol. 9(4), p. 1-15. URL: https://doi.org/10.3390/admsci9040089

8. Lyubashits, V. Y, Lyakhov, V. P., Plotnikov, A. A., Voitenko, D. A., \& Sokolova, I. A. (2019). Local Government as a Form of Democracy in Russia. Journal of History Culture and Art Research, 8(3), 353-365. URL: http://dx.doi.org/10.7596/taksad.v8i3.2252

9.Фінанси. Курс для фінансистів: Навч. Посіб. / за ред. В.І. Оспіщева. К. : Знання, 2008. 567 с.

10. Government revenue, expenditure and main aggregates. Eurostat. URL: https://appsso.eurostat.ec.europa.eu/nui/show.do?dataset=gov_10a_main\&lang=en

11. Tax revenue as percentage of total general government tax revenue. Organisation for Economic Co-operation and Development (OECD): URL: https://data.oecd.org/tax/tax-revenue.htm

\section{References:}

1. Lisyak, L.V. and Dyachenko, M.K. (2019), Mizhbyudzhetni transferty yak instrument zabezpechennya sotsial'noekonomichnoho rozvytku rehioniv. [Intergovernmental transfers as a tool to ensure socio-economic development of regions]. Naukovyy visnyk Chernihivs'koho derzhavnoho instytutu ekonomiky i upravlinnya. [Scientific Bulletin of the Chernihiv State Institute of Economics and Management]. Series 1: Economics. vol. 2. pp. 55-59. [in Ukrainian].

2. Pokas, V.I. (2018), Formuvannya osnov finansovoyi avtonomiyi mistsevoho samovryaduvannya. [Formation of the foundations of financial autonomy of local self-government]. Finansy Ukrayiny. [Finance of Ukraine]. № 8. pp. 67-73. [in Ukrainian]. 
3. Lunina, I.O. (2006), Derzhavni finansy ta reformuvannya mizh byudzhetnykh vidnosyn: monohrafiya. [Public finance and reform between budgetary relations: monograph]. K .: «Scientific thought». 432 p. [in Ukrainian].

4. Prots, N.V. (2015), Formuvannya podatkovykh nadkhodzhen' mistsevykh byudzhetiv $v$ konteksti byudzhetnoyi detsentralizatsiyi. [Formation of tax revenues of local budgets in the context of budget decentralization]. Finansovyy prostir. [Financial space]. №1(17). pp..221-227. [in Ukrainian].

5. Bondarenko, A.I. (2010), Vplyv derzhavy na formuvannya mistsevykh byudzhetiv u krayinakh Yevropy. [The influence of the state on the formation of local budgets in European countries]. Teoriya ta praktyka derzhavnoho upravlinnya. [Theory and practice of public administration]. URL: http://nbuv.gov.ua/UJRN/Tpdu_2010_4_30. [in Ukrainian].

6. Boadway, Robin W., and Anwar Shah. ( 2009), Fiscal Federalism: Principles and Practice of Multiorder Governance. Cambridge: Cambridge University Press, p. 620. [in English].

7. Fandel, P, Marišová, E., Malatinec, T. \& Lichnerová, I. (2019), Decentralization Policies in Public Administration in Slovakia and the Czech Republic, and Their Impact on Building Offices' Scale Efficiency. Administrative Sciences, MDPI, Open Access Journal, vol. 9(4), p. 1-15. URL: https://doi.org/10.3390/admsci9040089 [in Slovakia].

8. Lyubashits, V. Y, Lyakhov, V. P., Plotnikov, A. A., Voitenko, D. A., \& Sokolova, I. A. (2019). Local Government as a Form of Democracy in Russia. Journal of History Culture and Art Research, 8(3), 353-365. URL: http://dx.doi.org/10.7596/taksad.v8i3.2252

9. Finances. Course for financiers: Textbook. The method. / for ed. VI Ospischeva. K .: Knowledge, 2008. 567 p. [in Ukrainian].

10. Government revenue, expenditure and main aggregates. Eurostat. URL: https://appsso.eurostat.ec.europa.eu/nui/show.do?dataset=gov_10a_main\&lang=en

11. Tax revenue as percentage of total general government tax revenue. Organisation for Economic Co-operation and Development (OECD): URL: https://data.oecd.org/tax/tax-revenue.htm

Дата подання публікації 10.03.2021p. 